\title{
The Impact of Online Advertising on Tunisian Consumers' Purchase Intention
}

\author{
Salem Ben Brahim \\ Université de Tunis El Manar, ERMA \\ Faculté des Sciences Economiques et de Gestion de Tunis \\ Campus Universitaire Farhat Hached El Manar, Tunis
}

Correspondence should be addressed to: Salem Ben Brahim; s.benbrahim@live.com

Received date: 3 September 2015; Accepted date: 15 December 2015; Published date: 29 January 2016

Academic Editor: Frédéric Jallat

Copyright @ 2016 . Salem Ben Brahim. Distributed under Creative Commons CC-BY 4.0

\begin{abstract}
The impact of online advertising on consumer behavior has been little studied and research on the topic reached mixed results. Our study focuses on the determinants of online advertising and the role of the mediating variable "attitude towards online advertising" in the relationship between perceived advertising value and consumer purchase intent. The results show that online advertising value depends positively on its informativeness, credibility and entertainment value. They also indicate that credibility and online advertising value affect consumers' attitude towards this type of advertising. Finally, we show that attitude plays a mediating role between perceived advertising value and purchase intent.
\end{abstract}

Keywords: online advertising value, attitude towards online advertising, purchase intent, mediator role.

\section{Introduction}

Today, Facebook has become one of the most solicited means of entertainment, a marketing tool and an advertising channel to which consumers have direct and interactive access. This led advertisers to integrate this channel into their marketing strategy. Thus, ads that are channeled through traditional advertising media are now being run on Facebook. Assessment of online advertising value is a key element in shaping consumer attitudes towards it. Perceived value and the resulting attitude, in turn, have an impact on the purchasing behavior.
Our study puts an emphasis on the determinants of perceived value and on the causal relationships between value, attitude and purchase intent. Our interest in online advertising is justified by the fact that this field is not fully explored. In addition to the mixed results of previous research, research on the factors determining online advertising value and its impact on attitudes and purchase intent were little studied in the marketing literature. Therefore, our aim in this study is to find out the determinants of value, to assess the measurement scales of variables and investigate the mediating effect of attitude in the relationship value-purchase intent.

Cite this Article as: Salem Ben Brahim (2016), “The Impact of Online Advertising on Tunisian Consumers' Purchase Intention", Journal of Marketing Research \& Case Studies, Vol. 2016 (2016), Article ID 357783, 
Our paper is organized as follows: we first develop our conceptual framework and the hypotheses of our study. Then, we present the methodology adopted. Next, we report and analyze the obtained results. Finally, we present the implications and limitations of our study and we conclude with future research.

\section{Conceptual framework and research hypotheses}

Our study focuses on the direct and indirect impact of perceived value of online advertising on purchase intent. The study of the relationship between perceived value of online advertising, on the one hand, and attitude towards it and purchase intent, on the other, was the focus of several authors, including Wang et al. (2002, 2009); Ducoffe (1995,1996); Brackett and Carr, (2001); Kim and Hun (2014); Mehta (2000). Inspired by this line of this research, we extended their proposals in view of validating a model integrating the determinants of perceived value of online advertising and attitude towards online advertising and purchase intent. Online advertising value is influenced by the variables entertainment, credibility and informativeness, and in turn it acts on purchase intent, directly and indirectly, through attitude, which then acts as a mediating variable.

\section{Perceived value and its effects}

Value is defined as the relative preference of an interactive experience between a subject and an object (Holbrook, 1999; Aurier, Evard and N'Goala, 2001; Woodruff, 1997). The measurement scales of this concept, developed in the marketing literature, report to different approaches and vary from one field of research to another. In this study, we opted for the scale proposed by Ducoffe (1995). However, perceived value is itself a result of informativeness, credibility and entertainment provided by online advertising, (Wang et al., 2002; Ducoffe, 1995 and 1996, Brackett and Carr, 2001).

\section{Informativeness}

According to Wang et al. (2002), information is valued by its relevance. Advertising that provides information relevant to the needs may be actively processed and result in a response. For consumers, advertising is, among other things, information about the availability and quality of products. It has an informational role and has the ability to present a true picture of the products. Hence, we formulate the first hypothesis:

H1: Information content positively influences online advertising value.

\section{Credibility}

Credibility of advertising influences consumers' attitudes and behavior. Wang et al. (2002) found that credibility relates directly to value and attitude toward advertising. This result confirms the findings of Ducoffe $(1995,1996)$ and Brackett and Carr (2001), which stipulate that credibility impacts advertising value and attitude toward advertising. Therefore, we propose the following two hypotheses:

H2: Credibility positively influences online advertising value.

H3: Credibility has a positive effect on attitude toward online advertising.

\section{Entertainment}

Ability to entertain can improve the advertising experience. Ducoffe (1996) found a positive correlation between entertainment and advertising value. Similarly, Wang et al (2009) find that this factor brings pleasure and enjoyment. Then, our fourth hypothesis follows:

H4: Entertainment acts positively on online advertising value.

\section{Attitude towards online advertising}

Attitude towards online advertising is defined as the aggregation of assessments of perceived attributes. It results from the value that an individual attaches to. Furthermore, the concept of attitude is defined as a predisposition to respond, favorably or unfavorably, after an assessment of a phenomenon (Burton et al, 1998). Ducoffe (1996) shows that online advertising value positively relates to attitude towards it. Hypothesis H5 reflects this relationship. 
H5: Perceived value positively influences attitude towards online advertising.

\section{Purchase Intent}

Hun and Kim (2014) point out that few studies have investigated the direct effect of advertising value on purchase intent. They found that advertising value positively affects purchase intent. Hence, our sixth hypothesis:

H6: Online advertising value has a direct effect on purchase intent.

\section{The mediating role of attitude towards online advertising}

Consumers' attitude towards advertising influences their likelihood to purchase. Indeed, Mehta (2000) and Wang and Sun (2010) found that a positive attitude positively influences purchase intent and can result in frequent purchases. As we have assumed that attitude is induced by perceived value and that it acts on purchase intent, it seems that the variable "attitude" could play a mediating role in the relationship between value and purchase intent. Therefore, we formulate the following two hypotheses:

H7: Attitude towards online advertising has a positive impact on purchase intent.

H8: Attitude towards online advertising plays a mediating role in the relationship between advertising value and purchase intent.

In figure 1, we present the research model. We assume that the informativeness, entertainment and credibility determine perceived value of advertising, which in turn has a dual effect on purchase intent: a direct and an indirect effect through consumer attitude towards online advertising.

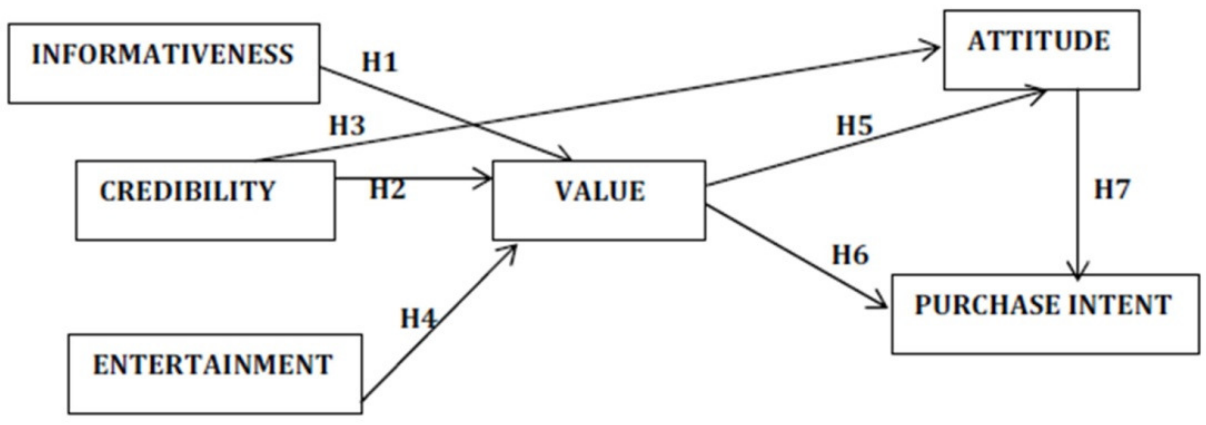

Figure 1: Conceptual Framework

\section{Methodology}

Our study examines a sample of 210 individuals. A questionnaire was administered online, with the fans of Tunisie Telecom's Facebook page. The measurement scales used and the items measuring our variables are taken from the literature and as such they have already been validated. Therefore, we are not in a scale development process, but rather in a scale confirmation process. Moreover, because any principal component analysis (PCA) should be followed by a confirmatory factor analysis (CFA), the step of running a PCA becomes doubly superfluous and therefore in our study we proceeded directly to a confirmatory factor analysis (CFA) using structural equation models (SEM) processed by AMOS software. In this phase, the retained estimation method is maximum likelihood. However, as the sample size (210) is relatively small, we run a bootstrap procedure at $95 \%$ confidence intervals, and this for all the estimated parameters of our model.

The model that we would like to test consists of six variables: advertising value, entertainment, informativeness, credibility, attitude toward advertising and purchase intent. In what follows, we present first the measurement scales of the independent 
variables, and then those of the dependent variables.

\section{The Independent variables}

To measure informativeness of online advertising, we adopted the scale developed by Ducoffe (1995). In this scale, informativeness consists of four items. Credibility of online advertising scale is taken from Wang (2009). This scale consists of three items. To measure Entertainment of online advertising, we have adapted the scales developed by Ling et al. (2010) and Wang (2009), retaining only five items.

\section{The Dependent variables}

The dependent variables in our model are Value of advertising, Attitude and Purchase Intent. To measure advertising value on a Facebook page, we used the scale of Ducoffe (1995). This scale consists of three items. As for attitude towards advertising on a Facebook page, we combined the scales developed by Zang et al. (2009) and by Ling et al. (2010). The retained scale thus consists of four items. Finally, we used the three-item scale of Kim et al (2010) to measure purchase intent.

\section{The Results}

\section{Characteristics of the sample}

Table 1: The sample

\begin{tabular}{|c|c|c|c|}
\hline & & Number & $\%$ \\
\hline \multirow{2}{*}{ Gender } & Females & 120 & 57,1 \\
\hline & Males & 90 & 42,9 \\
\hline \multirow{5}{*}{ Age } & Less than 20 years & 3 & 1,5 \\
\hline & between 20 and 29 years & 89 & 42,5 \\
\hline & between 30 and 39 years & 57 & 27,4 \\
\hline & between 40 and 49 years & 44 & 20,3 \\
\hline & 50 and + & 17 & 8,3 \\
\hline \multirow{6}{*}{ Education } & Primary not fulfilled & 8 & 3,8 \\
\hline & Primary fulfilled & 8 & 3,8 \\
\hline & Secondary not fulfilled & 17 & 8,1 \\
\hline & Secondary fulfilled & 22 & 10,5 \\
\hline & University not fulfilled & 63 & 30 \\
\hline & University fulfilled & 92 & 43,8 \\
\hline \multirow{6}{*}{ Profession } & Senior executive & 22 & 10,5 \\
\hline & Junior executive & 31 & 14,8 \\
\hline & Trader & 5 & 2,4 \\
\hline & Liberal Professions & 37 & 17,6 \\
\hline & Laborer & 42 & 20 \\
\hline & Inactive & 73 & 34,8 \\
\hline \multirow{6}{*}{ Monthly income } & Less than $500 \mathrm{DT}$ & 107 & 51 \\
\hline & between 500 DT to less than 1000 DT & 64 & 30,4 \\
\hline & between 1000 DT to less than $1500 \mathrm{DT}$ & 21 & 10 \\
\hline & between 1500 DT to less than $2000 \mathrm{DT}$ & 9 & 4,3 \\
\hline & 2000 DT and above & 9 & 4,3 \\
\hline & Total & 210 & $100 \%$ \\
\hline
\end{tabular}

The structure of the sample, by gender, age, education, profession and income, is presented in Table 1. Our sample consists of
$57.1 \%$ females, and $71.4 \%$ less than 39 years. $73.8 \%$ of the participants had a higher education level, $34.8 \%$ are inactive and 
81.5\% have a monthly income lower than 1,000 dinars, or about 445 Euros.

\section{Estimation of the model}

We estimated the overall measurement model, with all its latent variables and items. Indeed, taking into account all the variables of the model is necessary to study the discriminant validity of the different scales. All items are measured on a five-point Likert scale. Items that have high standardized residuals were removed. The fit indices were selected on the basis of the recommendations of several authors (Schermelleh-Engel et al, 2003; Hooper et al, D., 2008; Hu et al 1999), (Table 2).

Table 2: Fit Indices of the model and required thresholds

\begin{tabular}{|l|l|l|l|l|l|l|l|}
\hline Indices & $\chi^{2} / \mathrm{dl}$ & RMSEA & SRMR & GFI & NFI & TLI & CFI \\
\hline Thresholds & $<3$ & $<0.05$ & $<0.03$ & $>0.9$ & $>0.95$ & $>0.95$ & $>0.95$ \\
\hline Value & 1.503 & 0.049 & 0.03 & 0.914 & 0.955 & 0.980 & 0.984 \\
\hline
\end{tabular}

As reported in Table 2, all fit indices meet the required thresholds. In addition, all estimated parameters are significant, with (CR) statistics well above 2, (Appendix 3A). Our overall measurement model can thus be accepted, and be subject of a study of reliability, convergent validity and discriminant validity.

\section{Reliability}

The reliability of a measurement scale corresponds to its ability to produce observations coherent with each other. It is assessed through Jöreskog's rho coefficient of internal consistency, which should be above 0.7 so that reliability is judged to be good.

\section{Convergent validity}

Convergent validity of a measurement scale refers to its ability to provide results similar to those obtained using the same type of measures. It is considered good when the individual t-test of each factor loading exceeds 1.96 . It is assessed by rho $\left(\rho_{\mathrm{vc}}\right)$ test whose value should exceed 0.5 .

\section{Discriminant validity}

Discriminant validity measures whether two theoretically distinct variables are distinct in reality. When the value of rho of a variable exceeds the square of the correlations between this variable and all other latent variables in the model, the construct is considered to represent good discriminant validity. Table 3 shows the indices of convergent validity and reliability $\left(\rho_{\mathrm{Vc}}\right.$ and $\rho_{\mathrm{F}}$.

Table 3: Reliability and convergent validity indices of scales

\begin{tabular}{|l|l|l|l|l|l|l|}
\hline INDICES & INFOR & CRED & ENTER & VALUE & ATTITUDE & PURCH INT \\
\hline$\rho_{\mathrm{F}}$ & 0,928 & 0,883 & 0,935 & 0,928 & 0,938 & 0,974 \\
\hline$\rho_{\mathrm{VC}}$ & 0,769 & 0,787 & 0,869 & 0,809 & 0,790 & 0,893 \\
\hline
\end{tabular}

The diagonal elements of Table 4 are the square roots of Rho $\left(\rho_{\mathrm{vc}}\right)$. They are all superior to the correlations between pairs of variables. We conclude then to a good discriminant validity of all measurement scales. 
Table 4: Discriminant validity estimates

\begin{tabular}{|l|l|l|l|l|l|l|}
\hline & INFOR & CRED & ENTER & VALUE & ATTITUDE & PURCH INT \\
\hline INFOR & 0,877 & & & & & \\
\hline CRED & 0,558 & 0,887 & & & & \\
\hline ENTER & 0,360 & 0,400 & 0,932 & & & \\
\hline VALUE & 0,778 & 0,622 & 0,525 & 0,899 & & \\
\hline ATTITUDE & 0,686 & 0,627 & 0,443 & 0,842 & 0,889 & \\
\hline PURCH INT & 0,512 & 0,515 & 0,301 & 0,645 & 0,730 & 0,945 \\
\hline
\end{tabular}

Reliability and convergent validity indices show that our measurement scales have good psychometric properties. They all have good reliability and good convergent validity. They also have a good discriminatory power.

\section{Test of our research hypotheses}

Estimation of the structural model was then conducted, since the scales of the variables of our model have been validated. The different equations modelling our hypotheses were tested simultaneously using AMOS software.
As for the estimation of the overall measurement model, we used the maximum likelihood method, coupled with a bootstrap procedure. We set the results of the different estimations at the $95 \%$ confidence intervals, for all the hypothesized relationships in our model. We first present the results of hypotheses $\mathrm{H} 1$ to $\mathrm{H} 7$.

\section{Testing hypotheses H1 to H6}

As shown in Table 5 below, the model provides good fit indices.

Table 5: The structural model's fit Indices

\begin{tabular}{|l|l|l|l|l|l|l|l|l|}
\hline Fit indices & $\chi^{2} / \mathrm{df}$ & RMSEA & GFI & AGFI & SRMR & NFI & TLI & CFI \\
\hline Values & 1.466 & 0.047 & 0.912 & 0.88 & 0.029 & 0.954 & 0.981 & 0.985 \\
\hline
\end{tabular}

Analysis of the results can thus be continued. Regression coefficients with the corresponding CR are reported in Table 6. In this table, it seems that all parameters are significant, with the exception of the relationship PURCHASE INT --- VALUE. Furthermore, the significant coefficients indicate the presence of positive effects.

Table 6: Estimation of the structural model

\begin{tabular}{|l|l|l|l|}
\hline & Régression Coefficients & CR & P \\
\hline VALUE<--- INFORMATIVENESS & 0.623 & 8.932 & $* * *$ \\
\hline VALUE <--- CREDIBILITY & 0.21 & 3.284 & $* * *$ \\
\hline VALUE <--- ENTERTAINMENT & 0.24 & 4.447 & $* * *$ \\
\hline ATTITUDE <--- VALUE & 0.742 & 10.617 & $* * *$ \\
\hline ATTITUDE <--- CREDIBILITY & 0.181 & 2.801 & $* * *$ \\
\hline PURCH INT <--- VALUE & 0.104 & 0.842 & 0.400 \\
\hline PURCH INT <--- ATTITUDE & 0.742 & 5.705 & $* * *$ \\
\hline
\end{tabular}


Therefore, perceived value of online advertising is determined by Informativeness, Credibility and Entertainment. The more online advertising provides information, the more credible and entertaining it is, the better it is perceived by Internet users. Hypotheses H1, H2 and H4 of our model are thus validated.

We note also that the effects of varying value and credibility on attitude are both positive and significant with respective $C R$ values of 10.617 and 2.801 (Appendix 3A). Hypotheses H3 and H5 are thus validated. The more people attach value to online advertising and the more this latter is credible in their eyes, the more they develop positive and supportive attitude towards it.

We should note that although the obtained indices (observable variables) violate the multinormality assumption required to use the maximum likelihood method to estimate the parameters of the research model, our conclusions about the significance of these indices remain valid, as confirmed by the confidence intervals provided by the bootstrap procedure (Appendix 3B). The only confidence interval having a negative lower bound is that of the regression coefficient of the relationship PURCH INT <--VALUE. Hypothesis H6 which assumes a direct effect of perceived value on purchase Intention is rejected.

\section{The mediating role of "Attitude"}

Let us reproduce the estimated regression equations between the three variables Value, Attitude and Purchase Intent (Appendix 2).

Attitude $=0.742$ Value +0.181 Credibility (1)

Purchase Intent $=0.724$ Attitude +0.104 Value (2)

To conclude to the existence of a mediating role, we should check that the exogenous variable "value of advertising" has a significant effect on the endogenous variable "Attitude" in equation (1). The second condition relates to checking the existence of a significant effect of the variable assumed to play a mediating role (Attitude) on the endogenous variable Purchase Intent in equation (2). Reviewing CR values presented in parentheses, these two conditions are met. Moreover, as we found a CR of 0.842 (Appendix 3A), the effect of the variable "value" is not significant in equation (2) and thus mediation is complete. This means that perceived value has no direct effect on purchase intent. Therefore, the influence of perceived value on purchase Intent is observable via Attitude, following perception of online advertising value.

It remains to confirm the presence of this effect by performing the Sobel test. The statistic obtained by this test is 5.0207> 2 . We reject the null hypothesis of a zero indirect effect and retain the existence of a comprehensive mediating role of Attitude in the relationship between perceived value and purchase Intent, and this with a firstrank risk of $5 \%$. It follows that hypotheses $\mathrm{H} 7$ and $\mathrm{H} 8$ are retained.

\section{Conclusions}

\section{Discussion of Results}

Our study contributes to understanding the impact of advertising value on attitude of Internet users and to determining its effects on purchase intent. We found that informativeness positively affects a customer's perceived value of online advertising. This result is consistent with the results of previous studies (Ducoffe, 1995 and 1996; Wang, 2009 and Ling et al, 2010), which indicate that informativeness of advertising positively affects consumer attitudes towards it. Informative online advertising is a valuable source of information about product features, promotions, etc. that customers look for. Visitors of TT Facebook page can minimize the risks inherent in the purchase of products and services and take full advantage of promotions through information provided by advertising they are exposed to on the page. Specifically, a high level of information about products and services reduces perceived risks which impacts attitude towards online advertising. The Facebook page should therefore provide information on products and services for users to generate a positive attitude that could lead to a purchase. Our results also indicate that Credibility acts positively on advertising value as well as attitude towards 
it. This result is consistent with the results of Wang (2002) and Adler and Rodman (2000), which found that credibility is directly linked to advertising value. MacKenzie and Lutz (1989) found also that credibility of advertising determines consumer perception of truth and reliability of advertising. Perceived value of advertising also depends on entertainment that users of the TT Facebook page feel.

With these results, we confirmed the positive effect of perceived value on consumer attitudes toward advertising. Attitude developed by consumers in turn acts on their purchase intent. Ling et al. (2010) and Damon et al. (2010) point out that consumer attitudes correlates with their purchase intent, while Kim et al. (2014) and Wang (2009) indicate that consumer attitude towards online advertising positively affects their intention to purchase. Consumer attitude towards online advertising also plays a vital role in their willingness to see the advertising message (Ling et al 2010). Brettel and Ralph (2012) and Kim et al. (2010) found that purchase intent is positively influenced by consumer attitudes.

However, we did not find any significant direct effect of perceived value on purchase intent. In fact, further analysis has allowed us to point out the mediating role of attitude in the relationship between Value and Purchase Intent. Our results indicate in fact that perceived value affects only indirectly purchase intention, and this through consumer attitudes towards online advertising.

\section{Implications for management}

The results of our study have implications for advertisers, and other agents who are interested in online advertising, specifically advertising in Facebook pages. Marketers and advertisers need to create credible and entertaining advertisements that provide value to customers and generate a positive attitude. Consequently, managers and advertisers should focus on creating value and informationally encapsulated messages for online advertising.

Indeed, the design of an informative, credible and entertaining advertising positively affects perception of its value. This perception influences later consumer attitudes towards advertising on Facebook pages. A positive attitude towards this type of advertising positively affects purchase intent. However, advertising on a Facebook page that is not appreciated by consumers might affect the company's brand image and create a negative attitude in them which ultimately can lead to losing customers.

\section{Limitations of the study}

This study has some limitations. Additional studies are needed to overcome these limitations. Firstly, the sample size is small (210 participants). Secondly, respondents were only fans of the TT Facebook page who are already sympathetic with the operator. Third, the questionnaire was administered online in French, and it should have been translated into Arabic to ensure that respondents perfectly understand its sections. In addition, further research in this field can be done in other countries to point to cultural aspects to enrich the literature and to identify other factors affecting advertising value and consumer attitude towards advertising targeting fans of Facebook pages.

\section{Future research}

Future studies may include other factors that could affect value of online advertising, which in turn influences consumer attitudes toward online advertising and the use of this type of advertising to buy. For instance, researchers may find out whether there are other variables with a moderating effect on advertising value and consumer attitudes towards online advertising. They can also explore other factors that may influence the behavior of Internet users and their intention to purchase.

\section{References}

1. Abdelkefi, MI. and Ben Brahim, S. (2015) 'Attitude à l'égard de la publicité mobile et intention de l'utiliser par les Tunisiens,' International Journal of Economics \& Strategic Management of Business Process, 5, 1-6.

2. Adlet, RB. and Rodman, G. (2000) 'Understanding human communication,' Harcourt College, New York. 
3. Aurier, P., Evrard, Y.and N'Goala, G. (1998) 'La valeur du produit aux yeux du consommateur,' Actes des XIV ème Journées des IAE, Nantes, Tome 1, 199-212.

4. Brackett, LK. and Carr, B. (2001) 'Cyberspace advertising vs. other media: consumer vs. mature student attitudes,' Journal of Advertising Research, 41(5), 23-33.

5. Breuer, R. and Brettel, M. (2012) 'Short and long-term effects of online advertising: differences between new and existing customers,' Journal of Interactive Marketing, 26(3), 155-166.

6. Burton, S., Lichtenstein, D., Netemeyer, R. and Garretson, J. (1998) 'A scale for measuring attitude toward private label products and an examination of its psychological and behavioral correlates,' Journal of the Academy of Marketing Science, 26 (4), 293-306.

7. Celebi, S. I. (2015) 'How do motives affect attitudes and behaviors toward internet advertising and Facebook advertising?,' Computers in Human Behavior, 51, 312-324.

8. Dehghani, M. and Tumer, M. (2015) 'A research on effectiveness of Facebook advertising on enhancing purchase intention of consumers,' Computers in Human Behavior, 49, 597-600.

9. Ducoffe, RH. (1995) 'How consumers assess the value of advertising,' Journal of Current Issues and Research in Advertising, 17(1), 1-18.

10. Ducoffe, RH. (1996) 'Advertising value and advertising on the web,' Journal of Advertising Research, 17 (1), 21-35.

11. Fornell, C. and Larcker, D.F. (1981) 'Evaluating structural equations models with unobservable variables and measurement error,' Journal of Marketing Research, 18, 3950 .

12. Gurviez, P. and Korchia, M. (2002) 'Proposition d'une échelle de mesure multidimensionnelle de la confiance dans la marque,' Recherche et Applications en Marketing, 17 (3), 1-21.
13. Holbrook, MB. (1999) 'Introduction to consumer value,' in Holbrook, M. B. (ed.), Consumer Value: A Framework for Analysis and Research, Routledge, London, 1-28.

14. Hooper, D., Coughlan, J. and Mullen M. (2008) 'Structural equation modeling: guidelines for determining model fit,' The Electronic Journal of Business Research Methods, 6 (1), 53 - 60 .

15. Hu, LT. and Bentler, P. (1999) 'Cut off criteria for fit indexes in covariance structure analysis: Conventional criteria versus new alternatives,' Structural Equation Modeling, 6 (1), 1-55.

16. Huang, J., Su, S., Zhou, L. and Liu, X. (2013) 'Attitudes toward the viral Ad: Expending traditional advertising models to interactive advertising,' Journal of Interactive Marketing, 27, 36-46.

17. Jaoued, L. and Chandon, J. L. (2007) 'Endossement par les célébrités en publicité: Rôle médiateur de la congruence avec l'image de soi,' Colloque de l'Association Française de Marketing, 1-31.

18. Kim, YJ. and Han, J. (2014) 'Why smartphone advertising attracts customers: A model of web advertising, flow, and personalization,' Computers in Human Behavior, 33, 256-269.

19. Kim, J., Kim, W. and Park, S. (2010) 'Consumer perception of web advertisement and motivation factors to purchase in the online shopping,' Computers in Human Behavior, 26, 1208 - 1222.

20. Ling, K.C., Piew, T. and Chai, L. (2010) 'Les déterminants de l'attitude des consommateurs envers la publicité,' Canadian Social Science 6 (4), 114-126.

21. Liu, C-L. E., Sinkovics, R. R., Pezderka, N. and Haghirian, P. (2012) 'Determinants of Consumer perceptions toward mobile advertising- A comparison between Japan and Austria?,' Journal of Interactive Marketing, 26, 21-32.

22. Mackenzie, S.B., Lutz, R. and Belch, G. (1986) 'The role of attitude toward the ad as a mediator of advertising effectiveness,' 
Journal of Marketing Research, 23 (2), 130143.

23. Mehta, A. (2000) 'Advertising attitudes and advertising effectiveness', Journal of Advertising Research, 40, 67-72.

24. Ravald, A. and Gronroos, C. (1996) 'The value concept and relationship marketing', European Journal of Marketing, 30 (2), 19-30.

25. Schermeller-Engel, K., Moosbrugger, $\mathrm{H}$. and Müller, H. (2003) 'Evaluating the fit of structural equation models: Tests of significance and descriptive goodness-of-fit measures,' Methods of psychological Research Online, 8 (2), 23-74.

26. Tai, HT. and Chang, S. (2005) 'The causal model of internet advertising effectiveness,' Asia Pacific Management Review, 10(1), 7892.

27. Taylor, G. (2011) 'The informativeness of on-line advertising,' International journal of Industrial Organization', 29, 668-677.

28. Tomaras, P. and Ntalianis, K. (2015) 'Evaluating the impact of posted advertisements on content sharing sites: an unsupervised social computing approach,'
Procedia-Social and Behavioral Sciences, 175, 219-226.

29. Wang, Y. and Sun, S. (2010) 'Assessing beliefs, attitudes, and behavioral responses toward online advertising in three countries,' International Business Review, 19, 333-344.

30. Wang. C., Zhang, P., R., Choi, R. and Eredita, M. (2002) 'Understanding consumers attitude toward advertising,' Eighth Americas Conference on Information Systems, Syracuse University.

31. Wang. Y., Sun, S., Lei, W. and Toncar, M. (2009) 'Examining beliefs and attitudes toward online advertising among Chinese consumers,' Direct Marketing: An International Journal, 3(1).

32. Woodruff R, B. (1997) 'Customer value: the next source for competitive advantage,' Journal of the Academy of Marketing Science, 25 (2), 139-153

33.Zeng, F., Huang, L. and Dou. W. (2009) 'Social factors in user perceptions and responses to advertising in online social networking communities,' Journal of Interactive Advertising, 110 (1), 1-13. 


\section{Appendix 1}

MODELE DE MESURE - SOLUTION STANDARDISEE

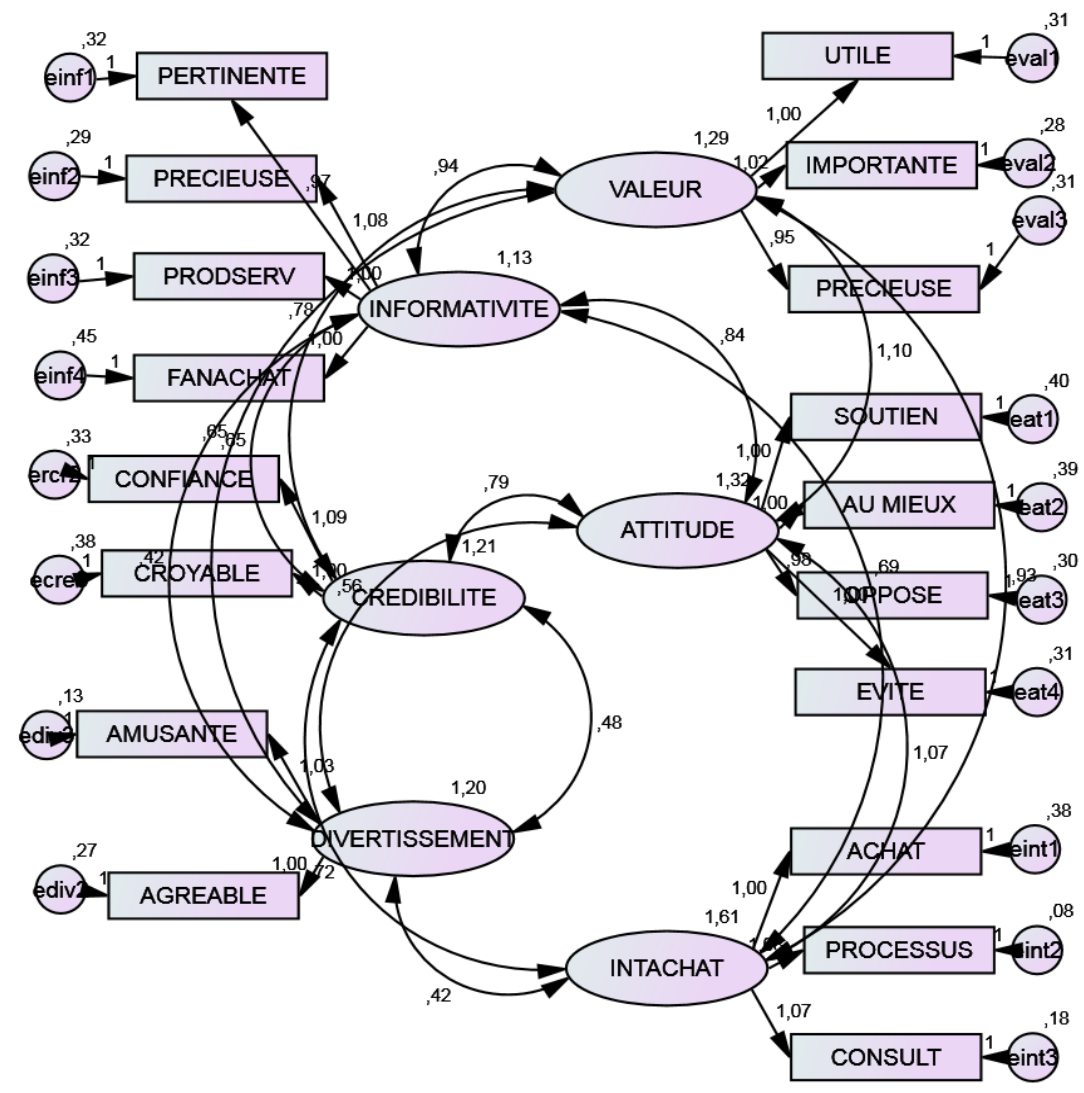

Chi2/ddl=1,503 RMSEA=,049 GFI=,914 NFI=,955 TLI=,980 CFI=,984 
Appendix 2

MODELE STRUCTUREL

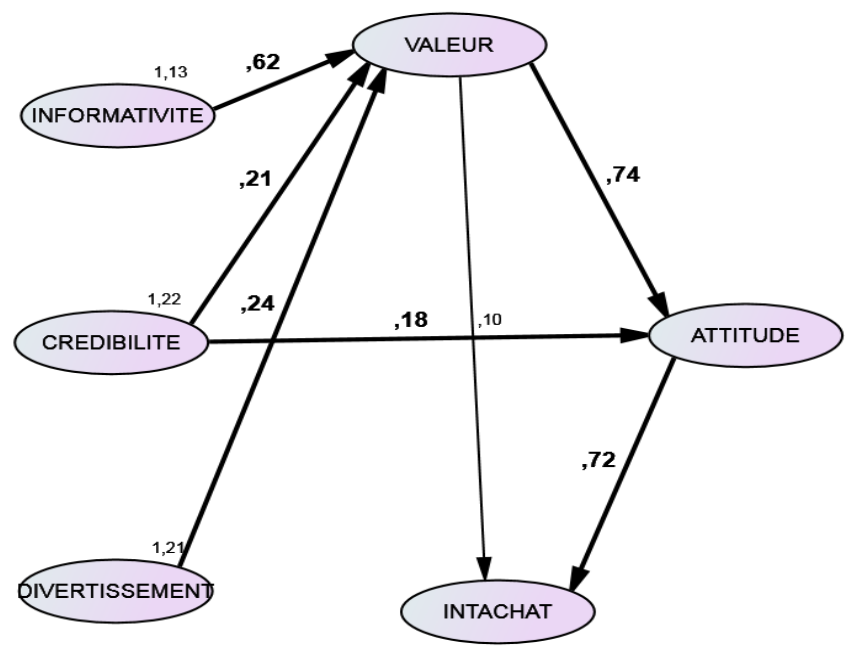

Chi2/ddl=1,466 RMSEA=,047 GFI=,912 NFI=,954 TLI=,981 CFI=,985

\section{Appendix 3}

Regression Weights:

\begin{tabular}{|l|l|l|l|l|l|l|l|}
\hline & & & Estimate & S.E. & C.R. & P & Label \\
\hline VALEUR & $<---$ & INFORMATIVITE &, 623 &, 070 & 8,932 & $* * *$ & \\
\hline VALEUR & $<---$ & CREDIBILITE &, 210 &, 064 & 3,284 &, 001 & \\
\hline VALEUR & $<---$ & DIVERTISSEMENT &, 240 &, 054 & 4,447 & $* * *$ & \\
\hline ATTITUDE & $<---$ & VALEUR &, 742 &, 070 & 10,617 & $* * *$ & \\
\hline ATTITUDE & $<---$ & CREDIBILITE &, 181 &, 065 & 2,801 &, 005 & \\
\hline INTACHAT & $<---$ & ATTITUDE &, 724 &, 127 & 5,705 & $* * *$ & \\
\hline INTACHAT & $<---$ & VALEUR &, 104 &, 123 &, 842 &, 400 & \\
\hline
\end{tabular}




\section{Appendix 4}

Regression Weights: Confidence intervals Bootstrap

\begin{tabular}{|l|l|l|l|l|l|c|}
\hline \multicolumn{2}{|l|}{ Parameter } & Estimate & Lower & Upper & $P$ \\
\hline VALEUR & $<---$ & INFORMATIVITE &, 623 &, 453 &, 792 &, 001 \\
\hline VALEUR & $<---$ & CREDIBILITE &, 210 &, 066 &, 371 &, 004 \\
\hline VALEUR & $<---$ & DIVERTISSEMENT &, 240 &, 102 &, 366 &, 001 \\
\hline ATTITUDE & $<---$ & VALEUR &, 742 &, 566 &, 922 &, 001 \\
\hline ATTITUDE & $<---$ & CREDIBILITE &, 181 &, 018 &, 357 &, 033 \\
\hline INTACHAT & $<---$ & ATTITUDE &, 724 &, 442 & 1,090 &, 001 \\
\hline INTACHAT & $<---$ & VALEUR &, 104 &,- 273 &, 406 &, 553 \\
\hline
\end{tabular}

